\title{
PARTISIPASI MASYARAKAT DALAM PELAKSANAAN STRATEGI NASIONAL PENCEGAHAN KORUPSI (STRANAS PK)
}

\author{
M. Fahrudin Andriyansyah \\ Fakultas Hukum Universitas Islam Malang \\ Jl. MT. Haryono Nomor 193, Malang, 65144, 0341 551932, Fax:0341 552249 \\ Email : fahrudin@unisma.ac.id
}

\begin{abstract}
The National Strategy on Corruption Prevention is a national policy direction that contains the direction of focus and targets for corruption prevention which are used as a reference for ministries, agencies, local governments and other stakeholders in implementing corruption prevention actions in Indonesia. The focus of the The National Strategy on Corruption Prevention includes licensing and commerce, state finances, and law enforcement. One of the challenges in the The National Strategy on Corruption Prevention is the lack of community involvement in these 3 focuses. Limited community involvement in these 3 (three) focuses is the background of the importance of strengthening participation of society in the implementation of The National Strategy on Corruption Prevention. Without community involvement in the corruption prevention agenda, the corruption eradication agenda will not run optimally. The Purpose of this researcher is to find how community participation in the implementation Stranas PK. The Research uses normatif law. Community involvement The National Strategy on Corruption Prevention can be done through the stages of formulating, implementing, monitoring, evaluating and reporting The National Strategy on Corruption Prevention.
\end{abstract}

Key words: Corruption, Prevention, Participation, Society

\section{ABSTRAK}

Strategi Nasional Pencegahan Korupsi (Stranas PK) adalah arah kebijakan nasional yang memuat arah fokus dan sasaran pencegahan korupsi yang digunakan sebagai acuan kementerian, lembaga, pemerintah daerah dan pemangku kepentingan lainnya dalam melaksanakan aksi pencegahan korupsi di Indonesia. Fokus Stranas PK meliputi perizinan dan tata niaga, keuangan negara, dan penegakan hukum. Salah satu tantangan dalam Stranas PK adalah minimnya pelibatan masyarakat pada 3 fokus tersebut. Terbatasnya pelibatan masyarakat pada 3 (tiga) fokus Stranas PK menjadi latar belakang pentingnya memperkuat partisipasi masyarakat dalam pelaksanaan Stranas PK. Tanpa adanya pelibatan masyarakat dalam agenda pencegahan korupsi maka agenda pemberantasan korupsi tidak akan berjalan secara maksimal. Tujuan penelitian ini yakni mengetahuai bagaimana partisipasi masyarakat dalam pelaksanaan Stranas PK. Penelitian ini menggunakan jenis penelitian yuridis normatif. Pelibatan masyarakat dalam Stranas PK dapat dilakukan melalui tahap penyusunan, pelaksanaan, pemantauan, evaluasi dan pelaporan Stranas PK.

Kata kunci: Korupsi, Pencegahan, Partisipasi, Masyarakat

\section{PENDAHULUAN}

Tahun 2020 menjadi titik mundur agenda pemberantasan korupsi di Indonesia, bagaimana tidak skor Corruption Perseption
Index (CPI) Indonesia mengalami penurunan dari tahun sebelumnya sebesar 40 menjadi 37. Hal ini menempatkan Indonesia diurutan 102 dari 180 negara yang disurvey. ${ }^{1}$ Salah satu

\footnotetext{
1 https://ti.or.id/indeks-persepsi-korupsi-2020-korupsi-respons-covid-19-dan-kemunduran-demokrasi/ diakses pada tanggal 22 April 2021
} 
penyebabnya adalah layanan publik yang minim integritas dan menurunnya kualitas demokrasi.

Berbanding lurus dengan turunnya skor CPI, tantangan pemberantasan korupsi kian hari kian berat terutama dengan telah dilakukannya perubahan atas UndangUndang Nomor 30 Tahun 2002 tentang Komisi Pemberantasan Korupsi menjadi Undang-Undang Nomor 19 Tahun 2019. Perubahan tersebut dilihat oleh banyak pihak sebagai upaya pelemahan agenda pemberantasan korupsi yang dilakukan oleh Komisi Pemberantasan Korupsi.

Peberantasan korupsi di Indonesia pada dasarnya dijalankan melalui 3 (tiga) agenda utama, yaitu agenda penindakan korupsi, agenda pencegahan korupsi dan agenda pendidikan anti korupsi. Tujuan dilakukannya penindakan adalah agar tidak ada orang yang berani melakukan korupsi karena akan dibayang-banyangi hukuman berat berupa pidana penjara, denda, pembayaran ganti rugi, dan pengembalian aset hasil korupsi. Agedan pencegahan bertujuan membuat seseorang tidak dapat melakukan korupsi, yakni dengan membangun sistem anti korupsi, menutup celah-celah dimungkinkannya korupsi, dan yang paling penting adalah dengan mengajak masyarakat terlibat dalam agenda pencegahan.

Sedangkan agenda pendidikan anti korupsi dilakukan guna memberikan pemahaman agar seseorang tidak melakukan korupsi dengan segala risiko dan akibatnya.

Agenda pencegahan korupsi di Indonesia mulai menguat ditandai dengan dikeluarkannya Peraturan Presiden Nomor 55 Tahun 2012 tentang Strategi Nasional Pencegahan dan Pemberantasan Korupsi Jangka Panjang Tahun 2012-2015 dan Jangka Menengah Tahun 2012-2014. Kebijakan pencegahan korupsi tersebut selanjutnya diubah dengan dikeluarkannya Peraturan Presiden Nomor 54 Tahun 2018 tentang Strategi Nasional Pencegahan Korupsi (untuk selanjutnya disebut Stranas PK) karena sudah tidak sesuai lagi dengan perkembangan kebutuhan pencegahan korupsi

Stranas PK adalah arah kebijakan nasional yang memuat arah fokus dan sasaran pencegahan korupsi yang digunakan sebagai acuan kementerian, lembaga, pemerintah daerah dan pemangku kepentingan lainnya dalam melaksanakan aksi pencegahan korupsi di Indonesia. Pemangku kepentingan lainnya adalah orang perseorangan, kelompok masyarakat, badan hukum, badan usaha, organisasi kemasyarakatan, praktisi, akademisi, asosiasi, mitra pembangunan, dan media massa yang terkait dengan penyelenggaraan Stranas PK. Fokus Stranas PK meliputi perizinan dan tata niaga, keuangan negara, dan penegakan hukum.

Tujuan dibentuknya Stranas PK adalah pertama, memberikan arahan tentang upaya- 
upaya yang perlu dilakukan oleh kementerian, lembaga, pemerintah daerah, dan pemangku kepentingan lain untuk mencegah korupsi. Kedua, mendorong program pencegahan korupsi yang berorientasi pada hasil (oucome) dan dampak (Impact), bukan hanya luaran kegiatan (output) dengan capaian yang terukur. Ketiga, Meningkatkan sinergi antara program pencegahan korupsi dengan kebijakan pemerintah pusat, pemerintah daerah, pemangku kepentingan mapun dengan kebijakan strategis Komisi Pemberantasan Korupsi. ${ }^{2}$

Implementasi Stranas PK selanjutnya dilaksanakan melalui aksi pencegahan korupsi. Aksi pencegahan korupsi (selanjutnya disebut Aksi PK) adalah penjabaran fokus dan sasaran Stranas PK dalam bentuk program dan kegiatan. ${ }^{3}$

Aksi pencegahan ini dipergunakan sebagai alat evaluasi untuk mengukur sejauh mana capaian terhadap program dan kegiatan pencegahan korupsi. Menteri, pimpinan lembaga, kepala daerah, dan pemangku kepentingan lainnya menyampaikan laporan pelaksanaan Aksi PK kepada Tim Nasional Pencegahan Korupsi setiap 3 (tiga) bulan sekali.

Terdapat banyak tantangan dalam 3 (tiga) fokus Stranas PK tersebut, salah satunya pada aspek minimnya pelibatan masyarakat. Pertama, masih terbatasnya pelibatan masyarakat untuk mengawasi perizinan di tingkat pusat dan daerah, Kedua, masih terbatasnya pelibatan masyarakat dalam pengawasan pengelolaan keuangan negara di tingkat pusat maupun daerah. Ketiga, lemahnya pengawasan sistem merit dalam manajemen Aparatur Sipil Negara (ASN), dan belum meratanya kualitas keterbukaan informasi serta partisipasi masyarakat dalam pengawasan layanan publik.

Berdasarkan laporan pelaksanaan Stranas PK triwulan VIII tahun 2020 menunjukan capaian atas sub-aksi sebesar $78.51 \%$ dari target $100 \%$ yang berarti masuk kategori baik. ${ }^{4}$ Namun, hasil pemantauan Stranas PK yang dilakukan Transparency International Indonesia (TII) menunjukan bahwa hadirnya Stranas PK terlihat sangat teknis dan birokratis, sebuah kebijakan anti korupsi nasional yang efektif sepatutnya melampaui kerja-kerja administratif.

Rencana-rencana aksi yang tertuang dalam kerangka Stranas PK masih bertumpu pada target-target administratif guna mematuhi capaian dokumen. Padahal jika mengacu pada tantangan fokus Stranas seharusnya dapat ditekankan pentingnya pelibatan publik secara lebih optimal dari

\footnotetext{
2 https://stranaspk.kpk.go.id/id/profil/profil-stranas-pk diakses pada tanggal 29 April 2021

3 Pasal 1 Peraturan Presiden Nomor 54 Tahun 2018 tentang Strategi Pencegahan dan Pemberantasan Korupsi. Lembaran Negara Republik Indonesia tahun 2018 Nomor 108.

4 Laporan Pelaksanaan Strategi Nasional Pencegahan Korupsi Triwulan VIII 2020, Tahun 2021, Sekretariat Nasional Pencegahan Korupsi (Setnas-PK), Hlm. 8.
} 
tahap penyusunan hingga pengawasan Aksi PK. Momentum penting perbaikan Stranas PK sebenarnya terletak pada penyusunan Aksi PK periode 2021-2022. Sayangnya proses perumusan Aksi PK 2021-2022 cenderung tertutup dan tidak memberikan ruang bagi publik untuk terlibat. ${ }^{5}$

Beberapa tahun sebelumnya Tranparency International Indonesia juga telah mengingatkan dan memberikan 2 (dua) rekomedasi atas pelaksanaan Sranas PK. Pertama, menyegerakan sosialisasi tentang keberadaan Stranas PK kepada publik karena publik belum cukup mengenal Stranas PK. Bagaimana publik dapat terlibat dalam pengawasan pelaksanaan atau implementasi Stranas PK jika publik belum mengerti sejauh mana Stranas PK dijalankan dan sejauh mana dampaknya bagi masyarakat. Kedua, perlu dikembangkan model keterlibatan para pemangku kepentingan di dalam pengelolaan stranas PK dan program-program aksinya di pusat dan di daerah. ${ }^{6}$

Bahwa agenda pencegahan korupsi bukanlah semata tugas dan wewenang kementerian, lembaga dan pemerintah daerah semata. Melainkan juga menitikberatkan peran pemangku kepentingan dalam hal ini adalah masyarakat.
Terbatasnya pelibatan masyarakat pada 3 (tiga) fokus Stranas PK menjadi latar belakang pentingnya memperkuat partisipasi masyarakat dalam pelaksanaan Stranas PK. Tanpa adanya pelibatan masyarakat dalam agenda pencegahan korupsi maka agenda pemberantasan korupsi tidak akan berjalan secara maksimal.

\section{PEMBAHASAN}

\section{Rencana Aksi Pencegahan Korupsi dalam} Strategi Nasional Pencegahan Korupsi (Stranas PK)

Pemberantasan tindak pidana korupsi adalah serangkaian tindakan untuk mencegah dan memberantas tindak pidana korupsi melalui upaya koordinasi, supervisi, monitoring, penyelidikan, penyidikan, penuntutan, dengan peran serta masyarakat berdasarkan peraturan perundang-undangan yang berlaku. ${ }^{7}$

Peran serta masyarakat merupakan unsur yang sangat penting dalam agenda pemberantasan korupsi. Pelibatan masyarakat merupakan bagian dari agenda pencegahan terhadap tindak pidana korupsi.

Strategi Nasional Pencegahan Korupsi disusun guna mendorong upaya pencegahan korupsi yang lebih efesien dan efektif. Upaya pencegahan korupsi akan lebih efektif jika

\footnotetext{
5 Tranperency International Indonesia dan Indonesia Corruption Watch, (2020), Pemantauan Satu Tahun Kinerja Komisi Pemberantasan Korupsi Penguatan Semu Pemberantasan Korupsi, Hlm. 39.

6 Kertas Kerja Strategi Nasional Pencegahan Korupsi, (2018), "Lebih Fokus, terukur, dan dikelola secara inklusif, Transparency International Indonesia, Hlm. 2.

7 Pasal 1 angka 3 Undang-Undang Nomor 30 Tahun 2002 tentang Komisi Pemberantasan Korupsi sebagaimana yang telah diubah oleh Undang-Undang Nomor 19 Tahun 2019.
} 
difokuskan pada sektor-sektor strategis yang mempengaruhi kinerja pembangunan dan kepercayaan masyarakat terhadap pemerintah. Pencegahan korupsi akan lebih efesien apabila dibangun kerjasama yang terintegrasi antara kementerian, lembaga, pemerintah daerah, pemangku kepentingan (masyarakat) dan Komisi Pemberantasan Korupsi.

Fokus Stranas PK yang tertuang dalam Peraturan Presiden Nomor 54 Tahun 2018 tentang Strategi Nasional Pencegahan Korupsi adalah Perizinan dan Tata Niaga, Keuangan Negara, dan Penegakan Hukum dan Reformasi Birokrasi. Fokus tersebut selanjutnya dijabarkan melalui Aksi PK, yaitu: ${ }^{8}$

1. Aksi peningkatan pelayanan dan kepatuhan perizinan dan penanaman modal

a. Penghapusan surat keterangan domisili usaha dan izin gangguan (SKDU-HO).

Penghapusan ini bertujuan menyederhanakan prosedur perizinan usaha di daerah utamanya bagi UMKM lokal agar merangsang tumbuhnya investasi demi mendorong terbukanya lapangan kerja di daerah.

b. Percepatan One Single Submission (OSS)

Perizinan menjadi sektor yang menyumbang korupsi tertinggi, hal ini disebabkan karena ada banyak perizinan yang saling tumpang tindih antar satu dengan yang lainnya. Hal inilah yang mengakibatkan proses perizinan menjadi lama, mahal, dan tidak ada kepastian penyelesaian. Oleh karena itu dibentuklah pengintegrasian layanan perizinan di pusat dan daerah agar proses perizinan menjadi lebih sederhana, cepat dan murah.

2. Aksi perbaikan tata kelola data dan kepatuhan sektor ekstraktif, kehutanan, dan perkebunan.

a. Implementasi kebijakan satu peta (One Map).

Tumpang tindih pemanfaatan lahan, sengketa tanah, pembangunan yang tidak sesuai dengan tata ruang marak terjadi. Hal ini pula yang berkontribusi terhadap masifitas korupsi. Oleh karena itu dengan adanya kebijakan satu peta diharapkan ada dasar yang jelas sebagai rujukan bagi stakeholder terkait dalam pemanfaatan lahan dan ruang.

b. Penetapan kawasan hutan $(\mathrm{PKH})$

Sebagai salah satu negara dengan kawasan hutan terbesar di dunia, sepatutnya dilakukan penetapan kawasan hutan secara baik dan terencana. Hal ini penting agar pengelolaan, rehabilitasi kawasan

\footnotetext{
8 https://stranaspk.kpk.go.id/ diakses pada tanggal 24 April 2021
} 
hutan dapat berjalan dengan bertanggung jawab.

c. Penguatan dan pemanfaatan basis data benefecial ownership (BO)

Modus tindak pidana korupsi kian hari kian canggih, salah satunya adalah dengan memanfaatkan lembaga di luar sistem keuangan yaitu melalui perusahaan. Korporasi digunakan untuk menyembunyikan aset hasil dari tindak pidana korupsi dan pencucian uang. Oleh karena itu korporasi harus menyampaikan data siapa saja penerima manfaat atau keutungan yang diperoleh oleh korporasi yang bersangkutan kepada pemerintah atau lembaga terkait.

3. Aksi perbaikan utilitasi nomor induk kependudukan untuk perbaikan tata kelola pemberian bantuan dan subsidi.

Bantuan sosial dan subsidi yang tidak dibarengi dengan data penerima yang akurat menyebabkan pengalokasian anggaran menjadi tidak tetap sasaran. Di samping itu banyak pemberian bantuan dan subsidi dijadikan alat untuk kepentingan politik berbagai pihak untuk mendulang suara pada momen-momen pemilihan (Pemilu dan Pilkada). Hal inilah yang mendasari pentingnya penguatan basis data terpadu penerima bantuan sosial dan subsidi sehingga tidak rawan disalahgunakan.

4. Aksi integritas dan sinkronisasi data impor pangan strategis

Pemburu rente seringkali mendorong pemerintah untuk membuka keran impor dengan menciptakan kelangkaan pangan. Akibatnya hasil produksi petani dan peternak di jual murah karena dibanjiri oleh pangan yang berasal dari luar negeri. Kondisi ini tentu sangat merugikan petani dan peternak. Oleh karena itu diperlukan integrasi dan sinkronisasi data impor pangan yang dapat dijadikan sebagai dasar dalam perumusan kebijakan impor. Termasuk membentuk sistem indonesia national single window (INSW) untuk menjaga akuntabilitas dari pelaksanaan impor pangan

5. Aksi penerapan manajemen anti suap di pemerintahan dan sektor swasta

Suap menyuap merupakan modus yang paling banyak ditangai oleh Komisi Pemberantasan Korupsi, tercatat dari tahun 2004 sampai 2018 sebanyak 564 kasus. ${ }^{9}$ Sedangkan salah satu profesi terbanyak adalah swasta yaitu sebanyak 238 terpidana. $^{10}$ Kondisi ini mendesak

\footnotetext{
9 https://acch.kpk.go.id/id/statistik/tindak-pidana-korupsi/tpk-berdasarkan-jenis-perkara diakses pada tanggal 24 April 2021

${ }^{10}$ https://acch.kpk.go.id/id/statistik/tindak-pidana-korupsi/tpk-berdasarkan-profesi-jabatan diakses pada tanggal 24 Aprl 2021
} 
dilakukannya penerapan sistem anti suap di pemerintahan dan sektor swasta.

6. Aksi integrasi sistem perencanaan dan pengganggaran berbasis elektronik

Korupsi pada prinsipnya tidak dapat dilepaskan dari penyalanggunaan anggaran publik yang ada di dalam anggaran pendapatan dan belanja negara (APBN) dan Anggaran pendapatan dan belanja daerah (APBD). Modus korupsi sudah dimulai dari tahap perencanaan penggaran. Apa yang direncanakan dalam penyusunan anggaran dibuat bukan untuk kepentingan publik, melainkan sematamata untuk kepentingan pribadi atau golongan. Oleh karena itu, harus dibangun sistem perencanaan berbasis elektronik dengan tujuan agar proses perencanaan dan penggaran dapat dilakukan dengan akuntabel, transparan dan partisipatif.

7. Aksi peningkatan profesionalitas dan modernasi pengadaan barang dan jasa

a. Pembentukan unit kerja pengadaan barang dan jasa (UKPBJ)

Perlunya penguatan pada lembaga penyelenggara pengadaan barang dan jasa di dasarkan pada beberapa faktor. Pertama, salah satu modus korupsi yang cukup banyak adalah di sektor pengadaan barang dan jasa, sampai tahun 2018 Komisi Pemberantasan Korupsi telah menangi korupsi pengadaan barang dan jasa sebanyak 188 kasus. $^{11}$ Kedua, unit pengadaan barang dan jasa belum independen dan dibelum didukung dengan sumber daya manusia yang profesional.

Unit layanan pengadaan (ULP) dan kelompok kerja masih bersifat sementara atau addhock dan Unit layanan pengadaan (ULP) masih menjadi bawahan dari pejabat pembuat komitmen (PPK) sehingga rawan diintervensi, termasuk terpisahnya Unit layanan pengadaan (ULP) dnegan Layanan Pengadaan Secara Elektronik (LPSE). Oleh karena itu dengan adanya pembentukan Unit Kerja Pengadaan Barang dan Jasa (UKPBJ) diharapkan dapat menjadi penyelenggara pengadaan barang dan jasa yang independen tanpa adanya intervensi dari pihak manapun.

b. Implementasi $E$-Katalog

E-Katalog bukanlah kebijakan baru karena sudah mulai diinisiasi sejak tahun 2015. Namun hingga saat ini masih sedikit Kementerian, Lembaga dan Pemerintah Daerah yang menggunakannya. Penerapan EKatalog dapat meminimalisir potensi penggelembungan harga atau permainan harga yang berakibat pada pemborosan anggaran. Oleh karena

\footnotetext{
${ }^{11}$ https://acch.kpk.go.id/id/statistik/tindak-pidana-korupsi/tpk-berdasarkan-jenis-perkara diakses pada tanggal 24 April 2021
} 
diperlukan percepatan penerapan $E$ Katalog di seluruh Kementerian, Lembaga dan Pemerintah Daerah.

c. Penyempurnaan sistem kinerja penyedia (SIKAP)

Penyempurnaan sistem kinerja penyedia (SIKAP) merupakan aplikasi dalam sistem pengadaan secara elektronik (LPSE) yang digunakan untuk mengelola data/informasi mengenai riwayat kinerja dan/atau data kualifikasi penyedia barang dan jasa. Dengan adanya sistem ini akan terbangun iklim penyediaan barang dan jasa yang akuntabel dan berkualitas dengan didasarkan pada rekaman hasil kinerja penyedia terhadap penyediaan barang dan jasa yang telah dilakukannya. Penyedia akan secara otomatis menjadi pihak yang diundang dalam proses pengadaan barang dan jasa.

d. Konsolidasi pengadaan

Jika bisa disatukan kenapa harus dipisah? Inilah pertanyaan yang lazim ditanyakan dalam proses pengadaan barang dan jasa. Konsolidasi pengadaan merupakan penyatuan atau penggabungan pengadaan barang dan jasa yang sama di dalam kementerian, lembaga dan pemerintah daerah. Hal ini dilakukan untuk menyamakan rencana anggaran dan menghemat anggaran, karena jika dipisah-pisah akan ada banyak anggaran yang dibutuhkan untuk honor penyelenggara pengadaan.

e. Sentralisasi pengadaan

Pengadaan barang dan jasa yang bersifat kompleks adalah pengadaan barang/pekerjaan konstruksi/jasa lainnya yang mempunyai risiko tingi, memerlukan teknologi tinggi, menggunakan peralatan khusus. Oleh karena kapasitas penyelenggara pengadaan yang tidak mumpuni akan terjadi ketidakefisienan yang tinggi. Sehingga perlu dilakukan sentralisasi pengadaan.

8. Aksi optimalisasi penerimaan negara dari penerimaan pajak dan non pajak

Celah perpajakan seringkali dimanfaatkan untuk melakukan korupsi oleh petugas pajak dengan wajib pajak. Akibatnya potensi pendapatan yang diterima negara menjadi berkurang atau bahkah hilang. Oleh karena itu perlu adanya upaya pencegahan agar tidak ada kebocoran di sektor pendapatan negara ini.

9. Aksi penguatan pelaksanaan reformasi birokrasi

a. Percepatan sistem merit

Aparatur Sipil Negara (ASN) menjadi salah satu bagian penting sebagai aktor penggerak anti korupsi di pemerintahan. Sayangnya masih 
banyak aparatur sipil negara (ASN) yang masih mempraktekan jual beli jabatan. Penerimaan, mutasi sampai dengan kenaikan jabatan juga masih diselenggarakan secara tertutup. Oleh karena itu perlu dilakukan percepatan dalam membangun sistem anti jual beli jabatan dengan menempatkan aparatur sipil negara (ASN) berdasarkan kualifikasi, kompetensi, dan kinerja secara adil dan wajar tanpa membedabedakan latar belakannya.

b. Pembangunan zona integritas

Membangun zona integritas bukan semata memberikan status "zona bebas anti korupsi" atau semacamnya. Namun lebih dari itu zona integritas harus dibangun dengan mengutamakan pelayanan yang baik dan menghilangkan segala bentuk atau modus korupsi di sektor layanan publik. Misalnya pungutan liar, pemerasan dan suap menyuap.

c. Penguatan aparat pengasaan dan internal pemerintah

Aparat Pengawasan Internal Pemerintah (APIP) memiliki peran penting dalam upaya pencegahan korupsi yang ada dipemerintahan. Oleh karenanya perlu dilakukan penguatan terhadap peran dan fungsi aparat pengawasan internal pemerintah (APIP) dengan meningkatkan kualitas
SDM, memperkuat kelembagaan dan kewenangannya.

d. Penataan kelembagaan (Right Sizing)

Masalah klasik yang belum diperbaiki adalah banyaknya kelembagaan dengan fungsi yang sama atau tidak jauh berbeda. Akibatnya penyelenggaraan pemerintahan tidak dapat dijalankan secara efektif dan efesien.

e. Percepatan sistem pemerintahan berbasis elektorik (SPBE)

$$
\text { Perkembangan teknologi }
$$

informasi mendorong penyelenggaran pemerintahan dijalankan dengan menggunakan media elektronik. Namun, penggunaan media elektorik ini belum terstandarisasi dan belum padu satu dengan lainnya.

10. Aksi implementasi grand design strategi pengawasan keuangan desa

$$
\text { Banyaknya anggaran yang }
$$
dialokasikan kepada desa berbanding lurus dengan penyalahgunaan anggaran desa oleh aparat desa dengan aparat pemerintahan lainnya. Oleh karenanya pengawasan terhadap keuangan desa mutlak dilakukan agar penggunanaan keuangan desa berjalan secara transparan dan akuntabel. Salah satu caranya adalah meningkatkan integritas aparatur desa.

Titik rawan korupsi dalam proses pengelolaan keuangan desa terdiri atas 2 (dua) tahap, yakni perencanaan anggaran 
dan implementasi anggaran. Pada tahap perencanaan, yang seharusnya melibatkan masyarakat dalam berpartisipasi untuk membahasa bersama rencana anggaran pendapatan dan belanja desa melalui musyawarah desa, justru hanya diikuti oleh elit, orang terdekat Kepala Desa, dan perangkat desa. $^{12}$

11. Aksi perbaikan tata kelola sistem peradilan pidana terpadu

a. Implementasi sistem peradilan pidana terpadu berbasis teknologi informasi (SPPT-TI) dan Implementasi surat pemberitahuan dimulainya penyidikan (SDP) online .

Salah satu tantangan penegakan hukum di indonesia adalah penegakan hukum belum dilakukan secara adil dan transparan. Publik seringkali kesulitan untuk mengakses perkembangan laporannya. Oleh karena itu dengan adanya sistem peradilan pidana terpadu dan surat pemberitahuan dimulainya penyidikan online diharapkan dapat menjadi media untuk memadukan upaya penegakan hukum yang dilakukan oleh masing-masing penegak hukum sekaligus mempermudah masyarakat mendapatkan informasi perkembangan penegakan hukum. b. Penyusunan pedoman penuntutan

Disparitas penuntutan dan putusan terhadap tindak pidana korupsi mengakibatkan ketidakadilan dalam upaya penindakan tindak pidana korupsi. Oleh karenanya perlu disusun pedoman penuntutan dan putusan oleh jaksa dan hakim sebagai acuan agar tidak terjadi disparitas.

\section{Pelaporan Strategi Nasional Pencegahan}

\section{Korupsi}

Pelaporan Stranas PK didasarkan pada target triwulan yang telah disusun oleh Tim Nasional Pencegahan Korupsi. Masingmasing kementerian, lembaga, dan pemerintah daerah telah diberikan target triwulan yang harus dipenuhi kepada Tim Nasional Pencegahan Korupsi. Berikut proses pelaporan Stranas $\mathrm{PK}^{13}$ :

1. Pelaporan atas Strategi Nasional Pencegahan Korupsi dilakukan melalui aplikasi monitoring Stranas PK melalui https://jaga.id atau via https://jaga.id/monitoring.

2. Data capaian target triwulan Aksi PK yang disampaikan dalam aplikasi monitoring tersebut merupakan hasil capaian target triwulan Aksi PK Instansi yang diketahui oleh pejabat berwenang di kementerian, lembaga, pemerintah daerah.

\footnotetext{
12 Riski Zakaria, (2020), Partisipasi Masyarakat dalam Pencegahan Korupsi Dana Desa: Mengenali Modus Operansi, Jurnal Integritas Komisi Pemberantasan Korupsi, No. 2, Vol. 6. Hlm. 272.

13 Pedoman pengisian aplikasi monitoring Strategi Nasional Pencegahan Korupsi (Stranas PK).
} 
3. Bukti pencapaian target triwulan Aksi PK, mewajibkan kementerian, lembaga, pemerintah daerah mengunggah dokumen data pendukung sesuai yang dipersyaratkan pada masing-masing target.

4. Capaian target triwulan Aksi PK yang telah diunggah oleh masing-masing kementerian, lembaga, pemerintah daerah akan diverifikasi oleh verifikator Stranas PK setelah berakhir pelaporan.

5. Nilai capaian Stranas PK yang dinyatakan sebagai nilai yang sah adalah nilai yang diberikan verifikator.

6. Pemangku kepentingan lainnya (masyarakat) dapat mengakases https://jaga.id dengan membuat akun untuk melakukan monitoring atas pelaporan yang dilakukan oleh kementerian, lembaga, pemerintah daerah.

Partisipasi Masyarakat dalam Strategi Nasional Pencegahan Korupsi

Konsep partisipasi tidak hanya mencakup proses perencanaan dan pelaksanaan tetapi partisipasi dalam penerimaan manfaat. Argumen yang disampaikan adalah adanya kemungkinan masyarakat tidak mendapat manfaat dari kontribusi yang diberikannya. Selain partisipasi dalam perencanaan dan penerimaan manfaat, Griesgraber dan Gunter menambahkan aspek lain, yakni evaluasi dengan mengartikan partisipasi sebagai suatu mekanisme yang melibatkan masyarakat dalam suatu program mulai dari tahap identifikasi sampai implementasi dan evaluasi. $^{14}$

Midgley kemudian menegaskan bahwa partisipasi masyarakat disebut tercapai apabila program yang diinginkan dan dimanfaatkan oleh masyarakat secara efektif terpelihara oleh masyarakat itu sendiri setelah semua dukungan eksternal berakhir. Secara praktis, pandangan ini dianggap lebih relevan karena mempertimbangkan kapasitas masyarakat dan mengakui adanya kebutuhan akan bantuan eksternal dalam pengembangan partisipasi masyarakat.

Dengan mempertimbangkan berbagai uraian tersebut, partisipasi masyarakat berarti mencakup peran serta dalam proses perencanaan, pelaksanaan, evaluasi, dan penerimaan manfaat dengan mempertimbangkan otonomi dan kemandirian masyarakat. ${ }^{15}$

Partisipasi masyarakat dalam Stranas PK adalah melibatkan peran serta masyarakat pada tahap penyusunan, pelaksanaan, pemantauan, evaluasi, dan pelaporan Stranas PK. Hal tersebut sebagaimana yang telah tertuang dalam dalam Pasal 9 Ayat (2) dan Ayat (3) Peraturan Presiden Nomor 54 tahun 2018 tentang Strategi Nasional Pencegahan Korupsi (Stranas PK).

\footnotetext{
${ }^{14}$ Khoirul Muluk, (2007), Menggugat Partisipasi Publik dalam Pemerintah Daerah, Malang; Bayu Media Publishing, Hlm. 48.

15 Ibid, Hlm. 51.
} 
Pelibatan peran serta kepentingan lainnya sebagaimana dimaksud pada ayat (1) dapat dimulai dari tahap penyusunan, pelaksanaan, pemantauan, evaluasi, dan pelaporan Stranas $P K$.

Tata cara pelibatan Pemangku kepentingan lainnya sebagaimana dimaksud pada ayat (1) diatur oleh Tim Nasional Pencegahan Korupsi”

Berdasarkan rumusan pasal di atas, pelibatan masyarakat diatur lebih lanjut oleh Tim Nasional Pencegahan Korupsi yang dikomandoi oleh Komisi Pemberantasan Korupsi. Sayangnya sampai tulisan ini ditulis belum ada aturan yang dibuat oleh Tim Nasional Pencegahan Korupsi mengenai tata cara atau pedoman pelibatan pemangku kepentingan yang dapat diakses oleh publik, terutama dalam website www.stranas-pk.id.

Namun demikian akan diuraikan bagaimana pelibatan masyarakat yang seharusnya dapat dilakukan dalam pelaksanaan Stranas PK berdasarkan pasal 9 Ayat (2) di atas.

Perlu dicatat partisipasi masyarakat dalam Stranas PK tidak hanya hanya terbatas pada kelompok masyarakat, organisisasi masyarakat sipil, akademisi saja tetapi juga harus menjangkau orang perorangan dan masyarakat secara luas. Partisipasi dalam Stranas PK tersebut dilakukan pada tahap penyusunan, pelaksanaan, pemantauan, evaluasi dan pelaporan Stranas PK.
1. Tahap Penyusunan

Penyusunan Stranas PK sejatinya dimulai sebelum dikeluarkannya Peraturan Presiden Nomor 54 Tahun 2018 tentang Strategi Nasional Pencegahan Korupsi. Namun yang menjadi pertanyaan apakah pada waktu itu masyarakat dilibatkan dalam penyusunannya?

Karena kebijakan Stranas PK telah ada, maka partisipasi masyarat dapat difokuskan pada penyusunan rencana aksi yang dilakukan 2 tahun sekali. sebagaimana Pasal 5 ayat (2) Presiden Nomor 54 Tahun 2018 tentang Strategi Nasional Pencegahan Korupsi menjelaskan bahwa dalam menyusun Aksi PK, Tim Nasional Pencegahan Korupsi berkoordinasi dengan kementerian, lembaga, pemerintah, dan pemangku kepentingan lainnya yang terkait.

Tim Nasional Pencegahan Korupsi yang terdiri dari Komisi Pemberantasan Korupsi, Kementerian Dalam Negeri, Kementerian Pendayagunaan Aparatur Negara dan Reformasi Birokrasi, dan Kepala Staf Kepresidenan wajib membuka ruang partisipasi agar masyarakat dapat memberikan masukan terhadap rencana aksi yang akan disusun.

2. Tahap Pelaksanaan

Pelibatan peran serta pada tahap pelaksanaan Stranas PK dilakukan dengan cara ikut terlibat dalam pelaksanaan 
rencana Aksi PK. Telah diuraikan sebelumnya mengenai 11 aksi dalam Stranas PK yang diturunkan dari 3 fokus Stranas PK yaitu Perizinan dan Tata Niaga, Keuangan Negara, Penegakan Hukum dan Peran serta masyarakat dalam tahap pelaksanaan dapat dilakukan melalui:

- Sektor Perizinan dan Tata Niaga

a. Terlibat dalam forum konsultasi perencanaan kebijakan perizinan, dan tata ruang baik di pemerintah pusat maupun pemerintah daerah. Masyarakat dapat memberikan masukan dan sekaligus memastikan bahwa kebijakan tersebut disusun dengan baik.

b. Terlibat dalam pengawasan perizinan dengan memastikan apakah perizinan dilakukan sesuai dengan peraturan perundangundangan yang ada. faktanya banyak pemberan izin yang tidak didasarkan pada peraturan perundang-undangan.

c. Terlibat dalam evaluasi pelaksanaan perizinan.

d. Terlibat dalam pengawasan basis data Benefecial Ownership (BO).

e. Terlibat dalam perbaikan utilitas nomor induk kependudukan untuk perbaikan tata kelola pemberian bantuan sosial, yaitu dengan menyampaikan infomasi sebenar- benarnya terhadap kelayanan penerima bantuan dan subsidi.

- Sektor Keuangan Negara

a. Terlibat dalam perencanaan penganggaran Anggaran Pendapatan dan Belanja Negara (APBN) dan Anggaran Pendapatan dan Belanja Daerah (APBD) mulai dari Musyawarah Rencana Pembangunan (Musrenbang) sampai dengan pengesahan Anggaran Pendapatan dan Belanja Negara (APBN) dan Anggaran Pendapatan dan Belanja Daerah (APBD).

b. Terlibat dalam pengawasan pelaksanaan Anggaran Pendapatan dan Belanja Negara (APBN) dan Anggaran Pendapatan dan Belanja Daerah (APBD), ikut memastikan bahwa anggaran yang dikeluarkan benar-benar dipergunakan secara efektif dan efesien.

c. Terlibat dalam evaluasi pelaksanaan Anggaran Pendapatan dan Belanja Negara (APBN) dan Anggaran Pendapatan dan Belanja Daerah (APBD).

d. Terlibat dalam perencanaan kebijakan pengadaan barang dan jasa.

e. Terlibat dalam pengawasan pengadaan barang dan jasa. 
f. Terlibat dalam evaluasi pengadaan barang dan jasa. Pengadaan barang dan jasa wajib dievaluasi untuk menilai apakah hasil pengadaan telah sesuai dengan apa yang direncanakan ataukah tidak.

g. Terlibat dalam pengawasan anggaran desa yang ada dalam Anggaran Pendapatan dan Belanja Desa.

- Sektor Penegakan Hukum dan Reformasi Birokrasi

a. Terlibat dalam evaluasi kinerja birokrasi dengan memberikan penilaian terhadap pelayanan yang telah diberikan;

b. Terlibat dalam pengawasan penegakan hukum tindak pidana korupsi yang dilakukan oleh Kepolisian, Kejaksaan, Pengadilan dan Komisi Pemberantasan Korupsi.

Keterlibatan masyarakat dalam tahap pelaksanaan akan dapat berjalan dengan baik jika Tim Nasional Pencegahan Korupsi dapat memastikan agar kementerian, lembaga dan pemerintah daerah membuka ruang keterlibatan masyarakat dalam pelaksanaan Stranas PK tersebut.

3. Tahap Pemantauan dan evaluasi

Pada tahap ini masyarakat dapat berperan serta untuk memastikan apakah
Kementerian, Lembaga dan Pemerintah Daerah telah menjalankan apa yang telah diatur dalam rencana aksi yaitu dengan melakukan check and recheck dengan kenyataan di lapangan. Misalnya dalam hal pengadaan barang dan jasa, tidak cukup kementerian, lembaga, dan pemerintah memberikan dokumen yang dibutuhkan kepada Tim Nasional Pencegahan Korupsi, namun perlu dipastikan apakah benar dalam proses pengadaan barang dan jasa sudah dilakukan sesuai dengan apa yang ada dalam rencana aksi pencegahan korupsi.

Hasil dari pemantauan dapat dijadikan bahan untuk memberikan masukan pada tahap evaluasi. Tim Nasional Pencegahan Korupsi juga harus memfasilitasi keterlibatan masyarakat dalam evaluasi.

4. Tahap Pelaporan Stranas PK

Kementerian, Lembaga dan Pemerintah Daerah melakukan pelaporan atas pencapaian target triwulan aksi pencegahan melalu tautan atau aplikasi Jaga.id. oleh karena itu mayarakat juga dapat terlibat memastikan agar Kementerian, Lembaga dan Pemerinta Daerah telah melaporkan target triwulan aksi pencegahan korupsi dengan mengaskes tautan Jaga.id.

Bentuk partisipasi masyarakat dalam Stranas PK dapat berubah sesuai dengan rencana aksi pencegahan korupsinya. Oleh 
karena itu Tim Nasional Pencegahan Korupsi sebagai penyelenggara Stranas PK harus membuat pedoman pelibatan masyarakat dalam Stranas PK. Dengan adanya pedoman tersebut diharapkan masyarakat lebih proaktif melibatkan diri dalam Stranas PK.

\section{KESIMPULAN}

Partisipasi masyarakat dalam Stranas PK dapat dilakukan melalui tahap penyusunan, pelaksanaan, pemantauan, evaluasi dan pelaporan Stranas PK. Pertama, pada tahap penyusunan dilakukan dengan terlibat dalam penyusunan rencana aksi. Kedua, pada tahap pelaksanaan, dilakukan dengan terlibat dalam pelaksanaan rencana aksi. Ketiga, pada tahap pemantauan dan evaluasi, dilakukan dengan terlibat dalam pemantauan dan evaluasi pelaksanaan rencana aksi. Keempat, pada tahap pelaporan, dilakukan dengan memantau target capaian laporan melalui tautan jaga.id.

\section{SARAN}

1. Tim Nasional Pencegahan Korupsi melakukan sosialisasi terhadap Stranas PK kepada masyarakat. Sehingga masyarakat mengetahui dan dapat terlibat dalam Stranas PK.

2. Tim Nasional Pencegahan Korupsi menyusun pedoman pelibatan masyarakat dalam Stranas PK.

3. Tim Nasional Pencegahan Korupsi memastikan Kementerian, Lembaga dan Pemerintah Daerah membuka ruang partisipasi dalam pelaksanaan Stranas PK.
4. Masyarakat secara aktif terlibat dalam penyusunan, pelaksanaan, pemantauan, evaluasi dan pelaporan Stranas PK.

\section{DAFTAR PUSTAKA \\ Peraturan Perundang-Undangan}

Undang-Undang Nomor 30 Tahun 2002 tentang Komisi Pemberantasan Korupsi

Peraturan Presiden Nomor 55 Tahun 2012 tentang Strategi Nasional Pencegahan dan Pemberantasan Korupsi Jangka Panjang Tahun 2012-2015 dan Jangka Menengah Tahun 2012-2014.

Peraturan Presiden Nomor 54 Tahun 2018 tentang Strategi Nasional Pencegahan Korupsi (Stranas PK)

\section{Buku}

Khoirul Muluk, (2007), Menggugat Partisipasi Publik dalam Pemerintah Daerah, Malang; Bayu Media Publishing.

Tranperency International Indonesia dan Indonesia Corruption Watch, (2020), Pemantauan Satu Tahun Kinerja Komisi Pemberantasan Korupsi Penguatan Semu Pemberantasan Korupsi.

Transparency International Indonesia, (2018), Kertas Kerja Strategi Nasional Pencegahan Korupsi, Lebih Fokus, terukur, dan dikelola secara inklusif.

Setnas PK, (2021), Laporan Pelaksanaan Strategi Nasional Pencegahan Korupsi Triwulan VIII 2020.

\section{Jurnal}

Riski Zakaria, (2020), Partisipasi Masyarakat dalam Pencegahan Korupsi Dana Desa: Mengenali Modus Operansi, Jurnal Integritas Komisi Pemberantasan Korupsi, No. 2, Vol. 6.

\section{Internet}

TII, Indeks Persepsi Korupsi 2020: Korupsi, Respons Covid-19 dan Kemunduran Demokrasi, 2021 https://ti.or.id/indekspersepsi-korupsi-2020-korupsirespons-covid-19-dan-kemunduran- 
demokrasi/ diakses pada tanggal 22 KPK, TPK Berdasarkan Profesi/Jabatan April 2021

Stranas PK, Profil Stranas PK, https://stranaspk.kpk.go.id/id/profil/pro fil-stranas-pk diakses pada tanggal 29 April 2021 https://acch.kpk.go.id/id/statistik/tindak -pidana-korupsi/tpk-berdasarkanprofesi-jabatan diakses pada tanggal 24 Aprl 2021

KPK, TPK Berdasarkan Jenis Perkara,

KPK, TPK berdasarkan jenis perkara, https://acch.kpk.go.id/id/statistik/tindak -pidana-korupsi/tpk-berdasarkan-jenishttps://acch.kpk.go.id/id/statistik/tindakperkara diakses pada tanggal 24 April 2021

pidana-korupsi/tpk-berdasarkan-jenis-perkara diakses pada tanggal 24 April 2021 